\title{
Biomonitoring of coastal marine waters subject to anthropogenic use: development and application of the biosensor Mosselmonitor ${ }^{\circledR}$
}

\author{
Nadia B. BARILE*, Mariaspina SCOPA, Sara RECCHI, Eliana NERONE \\ Istituto Zooprofilattico Sperimentale dell'Abruzzo e del Molise “G. Caporale”, Centro Sperimentale Regionale \\ per la Pesca ed Acquacoltura, Viale Marinai d'Italia 20, 86039 Termoli (CB), Italy
}

\begin{abstract}
The overall objective of this study was to develop a biological early warning system (Mosselmonitor®) on offshore platform to detect critical environmental situations. The experiment was conducted on oil off-shore platform called Rospo Mare B. This structure is located in the area in front of Molise coast line (Italy, Adriatic Sea), characterized by a depth of about $77 \mathrm{~m}$ and a bathymetry between 65 and $80 \mathrm{~m}$. The Mosselmonitor® works with eight mussels connected via specific sensors to PC for recording opening values of valves. A probe was installed inside the instrument to daily control of water $\mathrm{pH}$, dissolved oxygen, salinity and temperature. Water samples are weekly analyzed for heavy metals, organochlorine pesticide and suspended matter. During the entire observation period, closure alarms were predominantly detected $(99.9 \%$ ) and a decrease of $65 \%$ in alarms maximum duration was recorded from the fifth week. During the first month, none changes in water physicochemical parameters were observed so that affect the bivalves behavior. The only chemical parameter steadily detected in water was copper; its average concentrations were of $10 \mathrm{ppb}$. Detected alarms were not comparable to those recorded in the first month: this observation could be explained considering that mussels will be adapted to copper constant presence.
\end{abstract}

Keywords: Mosselmonitor®, biomonitoring, biosensor, mussel, anthropogenic areas, offshore platform.

\section{Introduction}

The Adriatic Sea is a semi-enclosed basin characterized by a high biodiversity but also a high anthropogenic pressure (residential areas, productive activities, tourism, unsustainable fishing and inputs of environmental contaminants). In fact, despite of its limited extension (approximately $138,000 \mathrm{~km}^{2}$ ), it presents many extraction platforms of hydrocarbon submarines gases with different structures and sizes as well as various environmental conditions. Since 1960, the increasing presence of offshore gas platforms has become a further potential source of marine pollution [1]. All operations dealing with the installation and activity of new off-shore platforms are currently subject to environmental risk assessment by law. In this context, it is essential to accurately evaluate the ecological effects of pollutants released by off-shore exploitation and production activities. Biodiversity preservation is necessary for correct ecosystems balances, durable biological resources exploitations and uniform economic benefits. Within biodiversity conservation, the marine water quality monitoring is a complex but necessary activity for coastal areas protection. Vulnerable areas like oil off-shore platforms could have a high impact on the environment so the use of a biological early warning system provides useful information for marine environmental protection.

The biological monitoring system Mosselmonitor ${ }^{\circledR}$ was based on the use of Mytilus galloprovincialis. This bivalve mollusks have been used as indicator organisms in environmental monitoring programs due to their wide distribution, sedentary lifestyle, tolerance to a large range of environmental conditions and because they are filter feeders with very low metabolism which allows the bioaccumulation of many chemicals in their tissues [2 - 5]. In this regard, use of biological early warning system Mosselmonitor ${ }^{\circledR}$ on different Adriatic platforms might permit the development of data bank useful for integrated management of coastal densely used or particularly vulnerable areas. The knowledge of bivalves behavioral response in different anthropic and natural environments (port areas, areas closed to urban and industrial discharges, natural reserves) would adopt this system in various contexts encouraging biomonitoring plans. This continuous monitoring would determine: the absence of pollutant synergic effects on the environment (abiotic and biotic ecosystem factors); reducing the risk of pollutants transfer to high trophic levels through the food web; reducing the impact on the coastal tourism. All this will certainly have a positive socio-economic

\footnotetext{
*Corresponding author e-mail: n.barile@izs.it
} 
relapse for coastal communities, fishing industry and tourism.

\section{Experimental}

The study marine area is located in front of Molise coast line and characterized by an average depth of about $77 \mathrm{~m}$ and a bathymetry between 65 and $80 \mathrm{~m}$. In this site an oil off-shore platform called Rospo Mare is present. The "Rospo Mare" structure consists of three platforms (A, B, C). The three platforms are connected with the ship named "Alba Marina" used for loading, unloading, storage of crude oil.

Considering several factors (working platform; types of mined ore; distance from the coast and location in areas easily accessible during the monitoring; necessity of a place sheltered from weather conditions) the second floor of Rospo Mare B platform was chosen for positioning the Mosselmonitor (Figure 1).

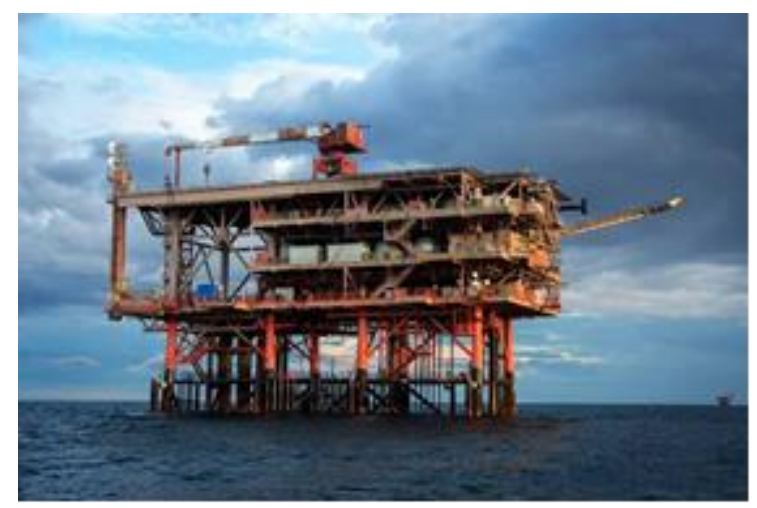

Figure 1. Rospo Mare B platform.

Eight mollusks, sampled from offshore aquaculture farm, have been placed into Mosselmonitor ${ }^{\circledR}$ and connected via specific sensors to the system for recording valvare openness values (Figure 2).

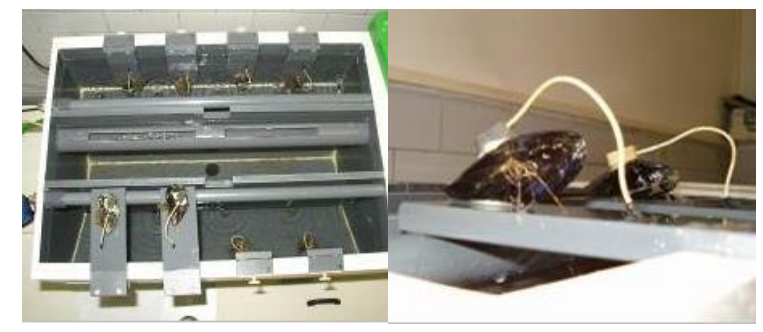

Figure 2. Placement of M. galloprovincialis into Mosselmonitor®.

By entering the movements of the shell into a microprocessor, and by carrying out certain calculations on this data, it is possible to ascertain the behavior of the mussel. By fitting a miniature coil to each half of the shell, the distance between the shell halves of a mussel can be measured. A highfrequency voltage is passed through the first coil, such that a magnetic field is created. This magnetic field induces a voltage in the other coil. The strength of the induced signal is dependent on the distance between the two coils, and is therefore indicative of the shell position. In natural condition bivalves open halves for respiration and feeding. In clean water, mussels move the two halves of their shells according to a characteristic pattern. They remain open for the majority of the time, and only close for short periods. A mussel in contaminated water behaves differently [6]. Depending on the type and level of contamination, mussels affect a movement pattern which can differ greatly from the normal pattern [7]. The variations on the normal movement pattern include a more rapid opening and closing of the shells (flapping), keeping the shell closed for a fixed period, opening the shell less and less far, and in the worst case death of the mussels (gaping). The various movements are as follows:

1. keeping the shell halves closed for a certain, longer period ( $C$ alarm);

2. an increased activity level, i.e. the mussel opens and closes more frequently than according to the normal behavior pattern "flapping" ( $A$ alarm);

3. a reduction in the average value of opening, normally $70-80 \%$, over a certain period of time (D alarm).

Mosselmonitor ${ }^{\circledR}$ was connected with a circuit composed of three tanks named TA01, TA02, TA03. The system can operate in closed or open cycle. In open mode, sea water is collected under platform to a depth of 3 meters and pumped into tank TA 01 equipped with a stainless steel mechanical float to control the maximum water level. From tank TA01 water is pumped into tank TA02 equipped with two sensors for controlling minimum and maximum water levels, and from there into the Mosselmonitor. Then water exits from Musselmonitor, enters into the third tank TA03 and finally returns into the sea. In closed mode the input pump, connected to tank TA01, and the discharge channel, connected to tank TA03, are turned off and system operates recycling sea water. The Mosselmonitor is also connected to a PC for online recording of opening values of valves necessary to estimate alarms. All alarms registration data and all chemical-physical parameters values are transferred in real time to a PC of Termoli laboratory through Internet connection. The system described above works for three months. Mussels were collected from offshore aquaculture farm localized in front of Termoli coast (Molise, Italy). During first week, the system was started with close cycle mode to evaluate mussel's response in potentially different environmental conditions; subsequently, the system was running in open cycle mode.

The physical-chemical parameters ( $\mathrm{pH}$, oxygen, salinity, temperature) were continuously monitored, by multiparametric probe IDROMAR IM5235 placed 
inside tank TA01. Physical-chemical data were analyzed by software APWIN.

Water samples, collected inside tank TA01, were weekly analyzed for detection of heavy metals and determination of suspended matter. Furthermore a water sample was collected for Polycyclic Aromatic Hydrocarbons (PAHs) detection and mussels, naturally present on platform legs, were sampled for metals and pesticides analyses.

Detection of heavy metals was conducted through ICP-MS (Inductively coupled plasma mass spectrometry). Suspended matter was determined with gravimetric method. Samples for polycyclic aromatic hydrocarbons and organochlorine pesticides were respectively analyzed with GC-LRMS (Gas Chromatography Coupled to Low Resolution Mass Spectrometry) and GC-ECD (Gas ChromatographElectron Capture Detector).

Every week, weather conditions permitting, inspections were carried-out to control the proper functioning of system, the status of installed mussels, to control multiprobe status, and to collect water samples for chemical analysis.

\section{Results and Discussions}

During the adaptation and monitoring phases, great variations of $\mathrm{pH}$, oxygen, salinity and temperature values weren't observed (Figures 3 and $4)$. It was noted a light increase in dissolved oxygen concentrations after the closed circuit system has been used in open cycle mode. A decrease of temperature values (about six degrees) was recorded according to typical seasonal fluctuations.

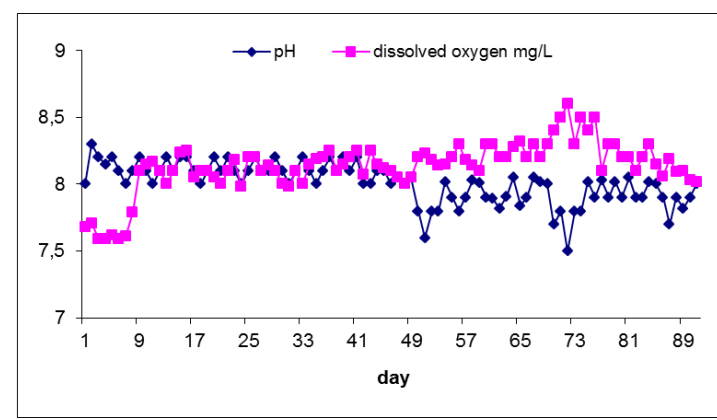

Figure 3. Temporal variation of $\mathrm{pH}$ and dissolved oxygen.

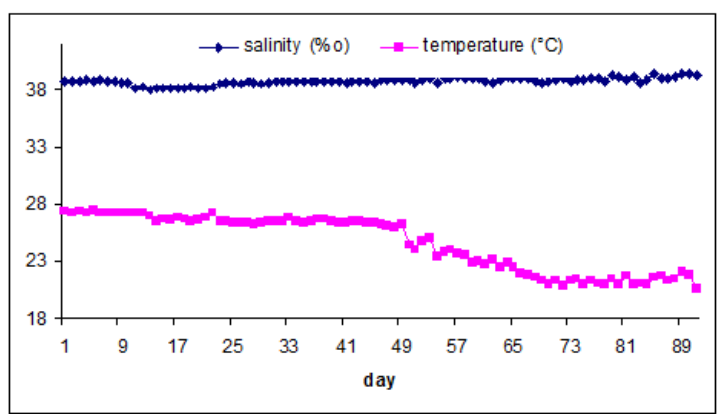

Figure 4. Temporal variation of salinity and temperature.
Considering suspended matter concentrations (Table 1), study area appears to have a moderate trophic load.

Polycyclic aromatic hydrocarbons (PAHs) concentrations found in water sample were in compliance with Ministerial Decree 56/2009 limits [8], in details total polycyclic aromatic hydrocarbons (PAHs) concentrations were $<0.05 \mu \mathrm{g} / \mathrm{l}$, benzo[a]pyrene were $<0.002 \mu \mathrm{g} / \mathrm{l}$, sum of benzo[k]fluoranthene and benzo[b]fluoranthene were $<0.005 \mu \mathrm{g} / \mathrm{l}$, sum of benzo[ghi]perylene and indeno(1,2,3-cd)pyrene were $<0.005 \mu \mathrm{g} / \mathrm{l}$.

Heavy metals and pesticides concentrations found in water samples (Table 1) are comparable to those reported for neighboring areas not impacted by oil extraction activities, except for copper. Considering all examined water samples, copper concentrations ranged between 9.2 and $148 \mathrm{ppb}$. Other studies focalized on platforms impact, including the evaluation of production water discharges, reported maximum concentrations of $20 \mathrm{ppb}$ [9]. It is noted that, among different water regulations, only the Legislative Decree No. 31/2001 [10] on human consumption waters requires a threshold limit for the parameter "copper" equal to $10 \mathrm{mg} / 1$. In particular, copper is not considered a priority substance for waters according to Decision No. 2455/2001/EC [11]. In fact it is not included in the list of priority and priority hazardous substances for surface waters (inland, coastal-marine, territorial and transitional) of the Ministerial Decree 56/2009 [8] in which the standards of quality in the water column with its limits for annual average values and maximum eligible concentrations are established.

Mussels collected on the platform legs did not exhibit a significant accumulation of trace metals (Table 2).

Heavy metals concentrations (copper, lead, cadmium and mercury) were lower than those previously reported for mussels collected near platforms or in control stations [12]. Furthermore, cadmium and mercury concentrations were comparable to those reported in Gorbi et al. 2008 [9]. Considering mercury, lead, and cadmium concentrations, obtained values resulted lower than those listed in Commission Regulation No. 1881/2006/EC [13]. In addition, also benzo[a]pyrene and sum of benzo(a)anthracene, benzo[a]pyrene, chrysene, benzo(b)fluoranthene values were in compliance with Commission Regulation No. 835/2011/EC [14].

During observation period, closure alarms (C) were predominantly detected $(99.9 \%)$, only one D alarm (decrease of valves' opening) was recorded for a duration of 15 minutes. In the first seven days, maximum closure alarms ranged from a minimum of 157 minutes and a maximum of 518 for a total number of 21 alarms. Subsequently, in the second, third and fourth week, alarm durations increased. In fact in the 
second week there was a maximum alarm of 892 minutes, in the third a maximum of 682 minutes and in the fourth a maximum of 753 minutes. All these alarms were generated by simultaneous closure of five mussels. Furthermore, during the first month, daily alarms were recorded with exception of three days. During the second month, maximum alarms durations considerably decreased, ranging from 450 minutes to 215 minutes. Furthermore, during this period, daily alarms were recorded with exception of five days. During the last five weeks, maximum alarms durations further decreased with a maximum of 250 minutes. All these alarms were generated by simultaneous closure of only four mussels and days without alarms registration increased up to thirteen.

Table 1. Water chemical concentrations during observation period.

\begin{tabular}{|l|c|c|c|}
\hline & \multirow{2}{*}{$\begin{array}{c}\text { Adaptation } \\
\text { phase }\end{array}$} & \multicolumn{2}{|c|}{$\begin{array}{c}\text { Monitoring } \\
\text { phase }\end{array}$} \\
\cline { 3 - 4 } & min & $\max$ \\
\hline $\begin{array}{l}\text { Esaclorobenzene } \\
\text { (ng/l) }\end{array}$ & $<4$ & $<4$ & $<4$ \\
\hline HCH (alfa) (ng/l) & $<2$ & $<2$ & $<2$ \\
\hline HCH (beta) (ng/l) & $<4$ & $<4$ & $<4$ \\
\hline Lindane (ng/l) & $<2$ & $<2$ & $<2$ \\
\hline Heptachlor (ng/l) & $<2$ & $<2$ & $<2$ \\
\hline $\begin{array}{l}\text { Heptachlor epoxide } \\
\text { (ng/l) }\end{array}$ & $<2$ & $<2$ & $<2$ \\
\hline $\begin{array}{l}\text { Endosulfan (alfa) } \\
\text { (ng/l) }\end{array}$ & $<2$ & $<2$ & $<2$ \\
\hline $\begin{array}{l}\text { Endosulfan (beta) } \\
\text { (ng/l) }\end{array}$ & $<2$ & $<2$ & $<2$ \\
\hline$o, p^{\prime}-$ DDD (ng/l) & $<5$ & $<5$ & $<5$ \\
\hline$p, p^{\prime}$ - DDD (ng/l) & $<4$ & $<4$ & $<4$ \\
\hline$o, p^{\prime}$ - DDT (ng/l) & $<3$ & $<3$ & $<3$ \\
\hline$p, p^{\prime}$ - DDT (ng/l) & $<3$ & $<3$ & $<3$ \\
\hline$p, p^{\prime}$ - DDE (ng/l) & $<3$ & $<3$ & $<3$ \\
\hline $\begin{array}{l}\text { Methoxychlor } \\
\text { (ng/l) }\end{array}$ & $<8$ & $<8$ & $<8$ \\
\hline Mirex (ng/l) & $<2$ & $<4$ & $<4$ \\
\hline Dieldrin (ng/l) & $<2$ & $<2$ \\
\hline Aldrin (ng/l) & $<p^{\prime}$ - DDE (ng/l) & $<2$ & $<2$ \\
\hline
\end{tabular}

Considering the entire observation period, there was a clear reduction of maximum alarms duration beginning from the fifth week: in fact average duration ranged from 711 minutes in the first month to 260 minutes in the others, with a decrease of $65 \%$ (Figure 5).

Table 2. Mussel chemical concentration.

\begin{tabular}{|c|c|}
\hline Esaclorobenzene (mg/kg) & $<0.001$ \\
\hline $\mathrm{HCH}$ (alfa) (mg/kg) & $<0.001$ \\
\hline HCH (beta) (mg/kg) & $<0.002$ \\
\hline Lindane (mg/kg) & $<0.001$ \\
\hline Heptachlor (mg/kg) & $<0.002$ \\
\hline Heptachlor epoxide $(\mathrm{mg} / \mathrm{kg})$ & $<0.002$ \\
\hline Endosulfan (alfa) (mg/kg) & $<0.004$ \\
\hline$o, p^{\prime}-\mathrm{DDD}(\mathrm{mg} / \mathrm{kg})$ & $<0.002$ \\
\hline$p, p^{\prime}-\mathrm{DDD}(\mathrm{mg} / \mathrm{kg})$ & $<0.002$ \\
\hline$o, p^{\prime}-\mathrm{DDT}(\mathrm{mg} / \mathrm{kg})$ & $<0.003$ \\
\hline$p, p^{\prime}-\mathrm{DDT}(\mathrm{mg} / \mathrm{kg})$ & $<0.003$ \\
\hline$p, p^{\prime}-\mathrm{DDE}(\mathrm{mg} / \mathrm{kg})$ & $<0.003$ \\
\hline Methoxychlor (mg/kg) & $<0.012$ \\
\hline Mirex $(\mathrm{mg} / \mathrm{kg})$ & $<0.002$ \\
\hline Dieldrin (mg/kg) & $<0.002$ \\
\hline Aldrin $(\mathrm{mg} / \mathrm{kg})$ & $<0.002$ \\
\hline$o, p^{\prime}-\mathrm{DDE}(\mathrm{mg} / \mathrm{kg})$ & $<0.002$ \\
\hline Lead (mg/kg) & 0.170 \\
\hline Copper $(\mathrm{mg} / \mathrm{kg})$ & 1.20 \\
\hline Cadmium (mg/kg) & 0.47 \\
\hline Mercury (mg/kg) & $<0.05$ \\
\hline Benzo[a]anthracene (microg/kg) & $<1.0$ \\
\hline Chrysene (microg/kg) & $<1.0$ \\
\hline Benzo[a]pyrene (microg/kg) & $<1.0$ \\
\hline Benzo[b]fluoranthene (microg/kg) & $<1.0$ \\
\hline
\end{tabular}




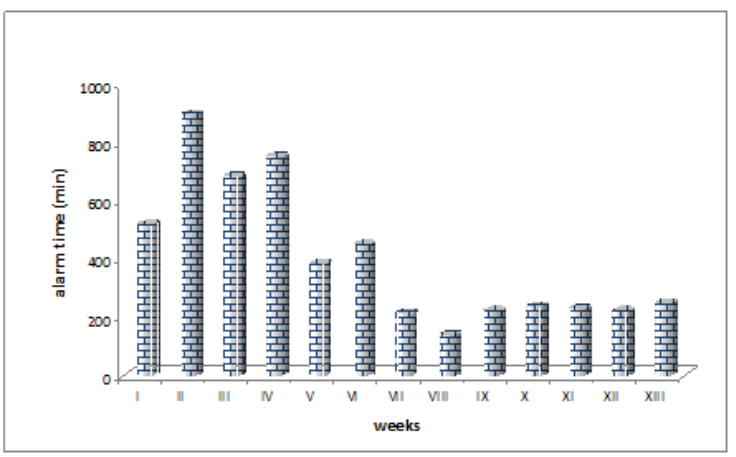

Figure 5. Maximum alarms duration during observation period.

This improvement is also evident observing variations of total number alarms recorded weekly, varying from 21 alarms in the first week to 3 in the tenth (Figure 6).

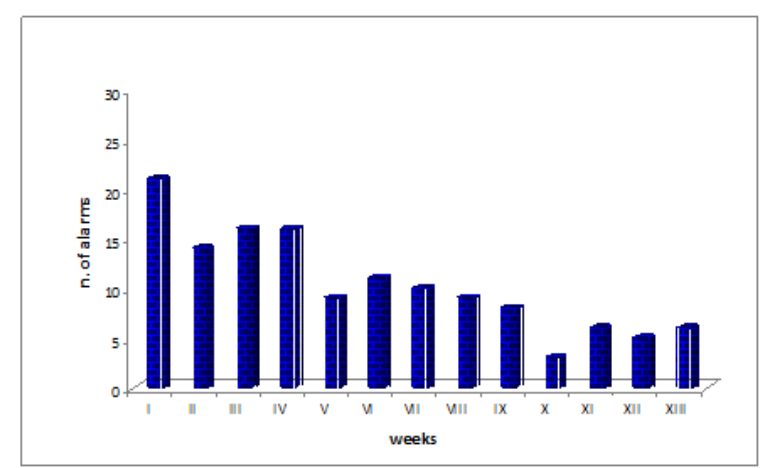

Figure 6. Alarms number during observation period.

During the first month, none changes in water physico-chemical parameters were observed so that affect the bivalves behavior. The only chemical parameter steadily detected in water samples was copper. The concentrations detected in this period were higher (about double) of LOEC (equal to 5ppb) determined in laboratory tests [15], so the presence of this metal could have influenced mussels behavior in the first month. Moreover, considering that mussels used came from a different environment, the recorded alarms could represent an adaptation to new habitat. Subsequently, the copper concentrations were recorded at average concentrations of $10 \mathrm{ppb}$, but detected alarms were not comparable to those recorded in the first month both in terms of duration and in terms of number. This observation could be explained considering that mussels will be adapted to an environment with a copper constant presence and therefore they responded positively with only physiological alarms. In particular, during last week, in presence of high copper concentrations (148 ppb), mussels didn't show changes in behavioral response if compared to those observed in previous period. This data suggests that in presence of high and persistent metal concentrations, such as copper, mussels, adapted to these conditions, show a decreased sensitivity respect to what observed in controlled laboratory conditions.

\section{Conclusions}

The Mosselmonitor ${ }^{\circledR}$ has proved to be an effective early warning system for instrumentation and biosensor characteristics. In fact, the instrument, characterized by continuous functioning, has a high degree of automation and requires minimal maintenance. It is also extremely versatile, as it can be calibrated to different sensitivity levels also in relation to the studied environment.

The data obtained in this study allowed to enlarge the knowledge on mussels behavior in impacted areas by human activities such as oil extraction platforms. However, the monitoring considered period doesn't permit to assess the seasonal changes of metals accumulation in mussels, of contaminants concentrations in the water, and especially of longterm biosensors behavioral response. Considering that a series of critical questions regarding the environmental effects of the offshore oil and gas production industry still remain unanswered, it would be useful to applicate Mosselmonitor ${ }^{\circledR}$ system in monitoring plans with annual scales and referred to different areas. The use of biological early warning system Mosselmonitor ${ }^{\circledR}$ on different Adriatic platforms might permit the development of data bank useful for integrated management of coastal areas and the bivalves behavioral response in different anthropic and natural environments (port areas, areas closed to urban and industrial discharges, natural reserves) would adopt in various contexts encouraging biomonitoring plans.

\section{Conflict of interests}

The authors declare that there is no conflict of interests.

\section{References}

[1]. D.A. Holdway, Marine Pollution Bulletin 44, 3 (2002)

[2]. J. Widdow and P. Donkin, Mussels and environmental contaminants: bioaccumulation and physiological aspects. In: The Mussel Mytilus: Ecology, Physiology, Genetics and Culture (edited by Gosling, E.), pp. 383-424, Elsevier (1992).

[3]. S. Barreto and K.J.M. Kramer, Application of the Biological Early Warning System Musselmonitor ${ }^{\circledR}$ in monitoring of chlorinated drinking water, Poster presentation, SETACEurope, 28 April - 01 May 2003, Hamburg, Germany.

[4]. D. De Zwart, K.J.M. Kramerr, and H.A. Jenner, Environmental Toxicology and Water Quality 10, 237 (1995). 
[5]. K.J.M. Kramer and J. Botterweg, Aquatic biological early warning systems: an overview. In: Bioindicators and environmental management, D.W. Jeffrey \& B. Madden (eds), Academic Press, London, pp. 95-126 (1991).

[6]. A. Wagenvoort, C. de Hoogh, K. Kramer, P. Engels, E. Penders, and K. Pikaar. Standardisation, quality assurance and data evaluation of on-line biological alarm systems. 3. Mosselmonitor ${ }^{\circledR}$ (Delta Consult, Kapelle, NL), KWR report BTO 2010.015, Kiwa Water Research, Nieuwegein, Netherlands, p. 59 (2007).

[7]. K.J.M. Kramer and E.M. Foekema, Biomonitors and Biomarkers as Indicators of Environmental Change 2, Environmental Science Research volume 56, pp. 59-87 (2001).

[8]. Decreto 14 aprile 2009, n. 56. Regolamento recante «Criteri tecnici per il monitoraggio dei corpi idrici e l'identificazione delle condizioni di riferimento per la modifica delle norme tecniche del decreto legislativo 3 aprile 2006, n. 152, recante Norme in materia ambientale, predisposto ai sensi dell'articolo 75, comma 3, del decreto legislativo medesimo». Gazzetta Ufficiale della Repubblica Italiana n. 124 del 30-5-2009 - Suppl. Ordinario n. 83.

[9]. S. Gorbi, C. Virno Lamberti, A. Notti, M. Benedetti, D. Fattorini, G. Moltedo, and F.
Regoli, Marine Environmental Research 65, 34 (2008).

[10]. Decreto Legislativo 2 febbraio 2001, n. 31 "Attuazione della direttiva 98/83/CE relativa alla qualita' delle acque destinate al consumo umano"pubblicato. Gazzetta Ufficiale della Repubblica Italiana n. 52 del 3 marzo 2001 Supplemento Ordinario n. 41.

[11]. Decision No. 2455/2001/EC of the European Parliament and of the Council of 20 November 2001 establishing the list of priority substances in the field of water policy and amending Directive 2000/60/EC.

[12]. A. Gomiero, L. Da Ros, C. Nasci, F. Meneghetti, A. Spagnolo, and G. Fabi, Marine Pollution Bulletin 62, 2483 (2011).

[13]. Commission Regulation (EC) No 1881/2006 of 19 December 2006 setting maximum levels for certain contaminants in foodstuffs.

[14]. Commission Regulation (EU) No 835/2011 of 19 August 2011 amending Regulation (EC) No $1881 / 2006$ as regards maximum levels for polycyclic aromatic hydrocarbons in foodstuffs.

[15]. N.B. Barile, G. Mascilongo, E. Nerone, S. Recchi, L. Bolelli, E. Ferri, and G. Girotti, Ovidius University Annals of Chemistry 19, 9 (2008).

Received: 22.08 .2016

Received in revised form: 25.10.2016

Accepted: 25.10.2016 